\title{
The evaluation of websites in the textile industry by applying ISO/IEC 9126-4 standard and the EDAS method
}

\author{
DOI: $10.35530 / I T .069 .06 .1520$
}

\begin{abstract}
DARJAN KARABASEVIC
DRAGISA STANUJKIC

MIODRAG BRZAKOVIC
\end{abstract}

MLADJAN MAKSIMOVIC PAVLE BRZAKOVIC

\section{REZUMAT - ABSTRACT}

\section{Evaluarea site-urilor web din industria textilă prin aplicarea standardului ISO/IEC 9126-4 și a metodei EDAS}

În zilele noastre, companiile moderne realizează cea mai mare parte a comunicării cu consumatorii lor pe Internet, de obicei pentru a-și promova propriile produse și servicii. În prezent, nu există nicio companie care să nu ișsi promoveze produsele și serviciile prin intermediul internetului și al site-urilor web. Prin urmare, măsurarea calității unui site web este semnificativă din punctul de vedere al companiei, pentru a menține avantajul competitiv pe termen lung; astfel, calitatea site-ului web a devenit un aspect de mare importanță. Lucrarea urmărește prezentarea unei noi abordări de luare a deciziilor cu mai multe criterii, împreună cu criteriile standardului de calitate ISO/IEC 9126-4 dedicate evaluării calității site-urilor web din industria textilă. Abordarea propusă se axează pe utilizarea noii metode de Evaluarea Bazată pe Distanța de la Soluția pe Termen Mediu (EDAS) pentru clasarea alternativelor, adică în cazul nostru site-urile web, în timp ce în scopul determinării ponderii, a fost aplicată metoda Analiza Raportului de Evaluare a Ponderii în Etape (SWARA). Pentru a demonstra utilitatea, eficiența și simplitatea, a fost realizat un exemplu numeric al evaluării site-urilor web ale industriei textile din Serbia.

Cuvinte-cheie: calitatea site-ului web, industria textilă, evaluare, EDAS, MCDM

The evaluation of websites in the textile industry by applying ISO/IEC 9126-4 standard and the EDAS method

Nowadays, modern companies perform the largest part of their communications with their consumers over the Internet, usually in order to promote their own products and services. There are almost no companies today that do not promote their products and services through the Internet and websites. Therefore, measuring the quality of a website is significant from the company's point of view in order to maintain the competitive advantage in the long run; thus, the quality of a website has become an area of great importance. This paper aims to present a new multiple-criteria decision-making approach, together with the "quality in use" ISO/IEC 9126-4 criteria devoted to the evaluation of the quality of websites in the textile industry. The proposed approach is based on the use of the newly-developed Evaluation Based on Distance from Average Solution (EDAS) method for the ranking of alternatives, i.e. in our case websites, whereas for the purpose of determining the weights, the adapted Step-wise Weight Assessment Ratio Analysis (SWARA) method is applied. In order to demonstrate usability, efficiency and simplicity a numerical example of the evaluation of the websites of the textile industry in Serbia is conducted.

Keywords: website quality, textile industry, evaluation, EDAS, MCDM

\section{INTRODUCTION}

The textile industry represents an important branch of the processing industry and is significant for the economy of a country. In the new era, the textile industry began to expand faster in the $18^{\text {th }}$ century. The textile industry in Serbia has a long tradition and is one of the most important branches of the processing industry [1]. It belongs to the traditional branches of the processing industry. As a rule, it employs a large number of low-cost and low-skilled, mostly female laborers, whose work is paid much less than in the other branches of the processing industry. The social aspect of this branch is, therefore, extremely important for all countries. The textile industry is the most global industry in the world, with as many as 26 million employees, which amounts to $15 \%$ of the world's industrial workforce. The share of the social product of the textile industry in industry in
1990 was $10.06 \%$, and in 1999 , it was $6.8 \%$. In the global context, this branch has undergone major changes since 1970, which coincides with the structural crises in developed countries, the globalization process and the accelerated liberalization of world trade [2]. The period of the development of the textile industry in the former Yugoslavia is referred to as the "golden age of the textile industry". At that time, more than 250,000 workers in the branch of the Republic of Serbia were employed in over a hundred factories [1]. The difficult political situation of the 1990s and the sanctions led to a fall in the share of Serbian textile factories in the market. After 2000, a very important branch of industry remained neglected. With the unsuccessful privatization process, almost all of the former textile giants were closed. For many years now, the unfavorable aspects of the textile enterprises market have reflected in a considerably low position on the world markets, unattainable competitiveness, 
obsolete equipment and technology, a drastic reduction in educated human resources and the insufficient training of the existing employees [3]. Also, Bratucu et al. point out that strong competition in this industry has forced companies to redirect their production to developing countries, which provide advantages from the aspect of legislative regulations, the policy, environmental protection regulations and, most importantly, labor costs [4].

An increasing and wider use of the Internet in everyday business has contributed to the development of the technological environment supportive of the integration of computer resources into business and manufacturing [5]. Today, the Internet represents a global multimedia distributed information system because it includes practically the whole world and allows not only access to the multimedia content distributed into space, but also the generation of a certain multimedia content based on the specific requirements of the users in the interactive mode [6]. Therefore, the Internet, as a global network, allows consumers to create an image of the actual value of a particular product and its benefits, which was impossible in earlier times in the case of the dominance of the one-way media. Today, the Internet offers companies a variety of web services, such as websites, to promote different content, products and services. Also, Hodge and Cagle point out that, since the introduction of the Internet and e-commerce in the mid-1990s, there has been a great deal of interference with the impact it will have on how companies operate and the changes in the global economy as a whole [7]. Lee and Kozar emphasize the fact that companies, due to increasing competition, are paying special attention to the importance of the quality of their websites in order to promote and/or sell their products and services [8]. Thus, the quality of the websites has become crucial for the acquisition of new consumers, as has been confirmed in numerous studies, such as: Al-Manasra et al. [9], Lin [10], Kim and Stoel [11], and so on.

The quality of websites has become an area of great importance. The quality of services, consumer services and customer satisfaction play an important role in the success and survival of websites, and these are the key elements a website should have in order for it to achieve good results. Therefore, the quality of websites is significant from a company's point of view, in order for a company to maintain the competitive advantage in the long run. So far, the WebQual model has been most frequently used to measure the quality of the website service [12], which is based on the principles of the SERVQUAL model [13]. On the other hand, official institutions in charge of standards and standardization, such as the ISO (International Organization for Standardization), are very seriously addressing the issue of quality and define the same as "the totality of characteristics of an entity that bear on its ability to satisfy stated and implied needs". It is also important to state that the ISO and the International Electrotechnical Commission have developed a metric for measuring and evaluating a software product. Within the above organizations, Working Group 6 have developed ISO/IEC 9126-1 (the quality model), 9126-2 (the external metrics), 9126-3 (the internal metrics), and 9126-4 (the quality-in-use metrics). These standards provide pragmatic guidance when it comes to the evaluation of software products [14-15].

Multiple-criteria decision-making methods (MCDM), as a part of operational research, are increasingly being used to solve a variety of problems. In due course of time, many MCDM methods have been proposed, such as: the AHP, the ANP, COPRAS, ARAS, SWARA, and so on [16]. Also, MCDM methods were successfully applied when the evaluation of websites is concerned [17-21].

Based on the previously stated, the newly-developed EDAS method and SWARA method will be used in this paper in order to evaluate websites in the textile industry in accordance with the ISO/IEC 9126-4 "quality-in-use" criteria, namely: Effectiveness; Efficiency; Satisfaction; Freedom from risk, and Context coverage. Therefore, the paper is organized as follows: Section 1 of this paper is the introduction. The methodology applied in the paper, more precisely the EDAS method, is presented in Section 2 and the SWARA method, is presented in Section 3. In Section 4, a numerical example of a website evaluation is shown. Finally, the conclusions are given in Section 5 .

\section{THE EDAS METHOD}

The EDAS (Evaluation Based on Distance from Average Solution) is developed by Keshavarz Ghorabaee et al. [22]. The EDAS method has largely found its application, which is confirmed by various extensions [23-36].

The basic concepts of the EDAS method are the use of two distance measures, namely the Positive Distance from Average (PDA) and the Negative Distance from Average (NDA), and that the evaluation of alternatives is performed according to the higher values of the PDA and the lower values of the NDA.

Based on Stanujkic et al. [25], the computational procedure of the EDAS method for a decision-making problem with $m$ criteria and $n$ alternatives can be presented as follows:

Step 1. Select the available alternatives, the most important criteria that describe the alternatives, and construct the decision-making matrix $X$, shown as follows:

$$
X=\left[\begin{array}{cccc}
x_{11} & x_{12} & \ldots & x_{1 n} \\
x_{21} & x_{22} & \ldots & x_{2 n} \\
\vdots & \vdots & \vdots & \vdots \\
x_{1 n} & x_{2 n} & \ldots & x_{m n}
\end{array}\right],
$$

where $x_{i j}$ denotes the performance rating of the alternative $i$ on the criterion $j$.

Step 2. Determine the average solution according to all of the criteria, shown as follows:

$$
x_{j}^{*}=\left(x_{1}, x_{2}, \ldots, x_{n}\right) \text {, }
$$


where

$$
x_{j}^{*}=\frac{\sum_{i=1}^{m} x_{i j}}{m} .
$$

Step 3. Calculate the positive distance from the average $d_{i j}^{+}$and the negative distance from the average $d_{i j}^{-}$, according to the type of the criteria (the benefit and the cost), shown as follows:

$$
\begin{aligned}
& d_{i j}^{+}=\left\{\begin{array}{l}
\frac{\max \left(0,\left(x_{i j}-x_{j}^{*}\right)\right)}{x_{j}^{*}} ; j \in \Omega_{\max } \\
\frac{\max \left(0,\left(x_{j}^{*}-x_{i j}\right)\right)}{x_{j}^{*}} ; j \in \Omega_{\min }
\end{array}\right. \\
& d_{i j}^{-}=\left\{\begin{array}{l}
\frac{\max \left(0,\left(x_{j}^{*}-x_{i j}\right)\right)}{x_{j}^{*}} ; j \in \Omega_{\max } \\
\frac{\max \left(0,\left(x_{i j}-x_{j}^{*}\right)\right)}{x_{j}^{*}} ; j \in \Omega_{\min }
\end{array}\right.
\end{aligned}
$$

where $\Omega_{\max }$ and $\Omega_{\min }$ denotes the set of the benefit criteria and the cost criteria, respectively.

Step 4. Determine the weighted sum of the PDA, $Q_{i}^{+}$, and the weighted sum of the NDS, $Q_{i}^{-}$, for all of the alternatives, as follows:

$$
\begin{aligned}
& Q_{i}^{+}=\sum_{j=1}^{n} w_{j} d_{i j}^{+}, \\
& Q_{i}^{-}=\sum_{j=1}^{n} w_{j} d_{i j} .
\end{aligned}
$$

Step 5. Normalize the values of the weighted sum of the PDA and the weighted sum of the NDA for all of the alternatives, shown as follows:

$$
\begin{aligned}
& S_{i}^{+}=\frac{Q_{i}^{+}}{\max _{i} Q_{i}^{+}}, \\
& S_{i}^{-}=1-\frac{Q_{i}^{-}}{\max _{i} Q_{i}^{-}},
\end{aligned}
$$

where $S_{i}^{+}$and $S_{i}^{-}$denote the normalized weighted sum of the PDA and the NDA, respectively.

Step 6. Calculate the appraisal score $S_{i}$ for all of the alternatives, as follows:

$$
S_{i}=\frac{1}{2}\left(S_{i}^{+}+S_{i}^{-}\right)
$$

Step 7. Rank the alternatives according to the decreasing values of the appraisal score. The alternative with the highest $S_{i}$ is the best choice among the candidate alternatives.

\section{THE SWARA METHOD}

The Step-wise Weight Assessment Ratio Analysis (SWARA) method was proposed by Kersuliene et al. [37]. The usability of the SWARA method has been proven in solving many MCDM problems, of which only several are mentioned [38-42].
The SWARA method has a certain similarity with the prominent AHP method. However, the computational procedures of the SWARA and the AHP methods significantly differ from one another.

The requirement that evaluation criteria should be sorted in descending order according to their expected significances can be mentioned as the weakness of the SWARA method, when it is compared with the AHP method. Therefore Stanujkic et al. proposed the use of the following equation for determining the importance of criteria as follows [43]

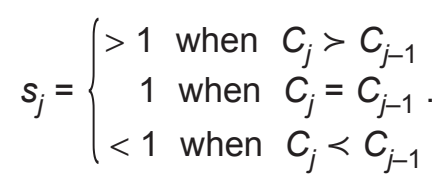

where: $s_{j}$ denotes the comparative importance of the criterion $j$, and $C_{j} \Theta C_{j-1}$ denotes the significance of the criterion $j$ in relation to the $j-1$ criterion.

Because of the above mentioned, the computational procedure of the adapted SWARA method, used in this article, could be precisely expressed by using the following steps:

Step 1. Choose the criteria on the basis of which an evaluation of alternatives will be carried out.

Step 2. Set the value of the relative importance of the criteria by using Eq. (11), starting from the second criterion. For the first criterion, the value of the relative importance of the criteria should be set to 1 .

Step 3. Calculate the coefficient $k_{j}$ for the criterion $j$ as follows:

$$
k_{j}=2-s_{j} .
$$

Step 4. Calculate the recalculated weight $q_{j}$ for the criterion $j$ as follows:

$$
q_{j}=\left\{\begin{array}{cl}
1 & \text { if } \quad j=1 \\
\frac{q_{j-1}}{k_{j}} & \text { when } j>1
\end{array} .\right.
$$

Step 5. Calculate the weights of the criteria as follows:

$$
w_{j}=\frac{q_{j}}{\sum_{k=1}^{n} q_{k}} .
$$

where $w_{j}$ denotes the weight of the criterion $j$.

\section{A NUMERICAL EXAMPLE OF the WEBSITE EVALUATION IN THE TEXTILE INDUSTRY}

In order to verify the proposed approach, a research study related to the quality of the websites of the four textile companies in Serbia was conducted.

In this case, the evaluation of the four websites was performed, namely: $A_{1}$ - http://www.spartan.rs/; $A_{2}-$ http://edi.rs; $A_{3}-$ http://www.elipsa.rs/ and $A_{4}-$ http://www.panter.co.rs/.

On the other hand, the evaluation of the above websites was carried out in relation to the following "quality-in-use" criteria: $C_{1}-$ Effectiveness; $C_{2}-$ Efficiency; $C_{3}$ - Satisfaction; $C_{4}-$ Freedom from risk, and $C_{5}-$ Context coverage. 
The evaluation of the alternatives, i.e. websites in our case, in relation to the selected criteria was carried out by a domain expert. At the very beginning of the evaluation, the domain expert assigned weights to the selected criteria. The weights of the criteria were determined by using the adapted SWARA method. The weights of the criteria are shown in table 1.

After determining the weights of the evaluation criteria, the domain expert performs an evaluation of the alternatives in relation to the selected criteria. Table 2 shows the result of the evaluation of the alternatives in relation to the evaluation criteria.

After that, the average solution is determined for each criterion by using Eq. (3). The obtained results are displayed in table 3 .

Table 1

\section{THE SIGNIFICANCE OF THE CRITERIA ASSIGNED} BY THE DOMAIN EXPERT

\begin{tabular}{|c|c|}
\hline Criteria & $\boldsymbol{E}_{\mathbf{1}}$ \\
\hline$C_{1}$ & 0.28 \\
\hline$C_{2}$ & 0.24 \\
\hline$C_{3}$ & 0.18 \\
\hline$C_{4}$ & 0.16 \\
\hline$C_{5}$ & 0.14 \\
\hline & 1 \\
\hline
\end{tabular}

Table 2

\begin{tabular}{|c|c|c|c|c|c|}
\hline \multicolumn{6}{|c|}{$\begin{array}{c}\text { THE RESULTS OF THE EVALUATION } \\
\text { OF THE ALTERNATIVES, OBTAINED FROM } \\
\text { THE DOMAIN EXPERT }\end{array}$} \\
\hline $\begin{array}{l}\text { Criteria } \\
\text { Alternatives }\end{array}$ & $C_{1}$ & $C_{2}$ & $C_{3}$ & $C_{4}$ & $C_{5}$ \\
\hline$A_{1}$ & 4 & 5 & 5 & 4 & 4 \\
\hline$A_{2}$ & 3 & 3 & 3 & 2 & 3 \\
\hline$A_{3}$ & 4 & 3 & 4 & 3 & 4 \\
\hline$A_{4}$ & 2 & 2 & 1 & 2 & 1 \\
\hline
\end{tabular}

Table 3

\begin{tabular}{|c|c|c|c|c|c|}
\hline \multicolumn{6}{|c|}{$\begin{array}{l}\text { THE AVERAGE SOLUTION OF EACH EVALUATION } \\
\text { CRITERION }\end{array}$} \\
\hline Criteria & $C_{1}$ & $C_{2}$ & $C_{3}$ & $C_{4}$ & $C_{5}$ \\
\hline$x_{j}^{*}$ & 3.25 & 3.25 & 3.25 & 2.75 & 3.00 \\
\hline
\end{tabular}

In the next step, the positive distance from the average $d_{i j}^{+}$and the negative distance from the average $d_{i j}^{-}$are determined by using Eq. (4) and Eq. (5), respectively. The obtained results are accounted for in tables 4 and 5 .

The weighted sum of the positive distance from the average, $Q_{i}^{+}$, and the weighted sum of the negative distance from the average, $Q_{i}^{-}$, are calculated by using Eq. (6) and Eq. (7), respectively, after which their normalized values, $S_{i}^{+}$and $S_{i}^{-}$, are determined by using Eq. (8) and Eq. (9). The mentioned values are shown in table 6.

Finally, the appraisal score $S_{i}$ of the considered alternatives is calculated by using Eq. (10). As can be seen from table 6 , the best-ranked alternative is the alternative denoted as $A_{1}$.

Table 4

THE POSITIVE DISTANCE FROM THE AVERAGE

\begin{tabular}{|c|c|c|c|c|c|}
\hline $\begin{array}{c}\text { Criteria } \\
\text { Alternatives }\end{array}$ & $\boldsymbol{C}_{\mathbf{1}}$ & $\boldsymbol{C}_{\mathbf{2}}$ & $\boldsymbol{C}_{\mathbf{3}}$ & $\boldsymbol{C}_{\mathbf{4}}$ & $\boldsymbol{C}_{\mathbf{5}}$ \\
\hline $\boldsymbol{A}_{\mathbf{1}}$ & 0.75 & 1.75 & 1.75 & 1.25 & 1.00 \\
\hline $\boldsymbol{A}_{\mathbf{2}}$ & 0.00 & 0.00 & 0.00 & 0.00 & 0.00 \\
\hline $\boldsymbol{A}_{\mathbf{3}}$ & 0.75 & 0.00 & 0.75 & 0.25 & 1.00 \\
\hline $\boldsymbol{A}_{\mathbf{4}}$ & 0.00 & 0.00 & 0.00 & 0.00 & 0.00 \\
\hline
\end{tabular}

Table 5

THE NEGATIVE DISTANCE FROM THE AVERAGE

\begin{tabular}{|c|c|c|c|c|c|}
\hline $\begin{array}{c}\text { Criteria } \\
\text { Alternatives }\end{array}$ & $\boldsymbol{C}_{\mathbf{1}}$ & $\boldsymbol{C}_{\mathbf{2}}$ & $\boldsymbol{C}_{\mathbf{3}}$ & $\boldsymbol{C}_{\mathbf{4}}$ & $\boldsymbol{C}_{\mathbf{5}}$ \\
\hline $\boldsymbol{A}_{\mathbf{1}}$ & 0.00 & 0.00 & 0.00 & 0.00 & 0.00 \\
\hline $\boldsymbol{A}_{\mathbf{2}}$ & 0.25 & 0.25 & 0.25 & 0.75 & 0.00 \\
\hline $\boldsymbol{A}_{\mathbf{3}}$ & 0.00 & 0.25 & 0.00 & 0.00 & 0.00 \\
\hline $\boldsymbol{A}_{\mathbf{4}}$ & 1.25 & 1.25 & 2.25 & 0.75 & 2.00 \\
\hline
\end{tabular}

Table 6

THE APPRAISAL SCORE AND THE RANKING ORDER OF THE CONSIDERED ALTERNATIVES

\begin{tabular}{|c|c|c|c|c|c|c|}
\hline Alternatives & $\boldsymbol{Q}_{\boldsymbol{i}}^{+}$ & $\boldsymbol{Q}_{\boldsymbol{i}}^{-}$ & $\boldsymbol{S}_{\boldsymbol{i}}^{+}$ & $\boldsymbol{S}_{\boldsymbol{i}}^{-}$ & $\boldsymbol{S}_{\boldsymbol{i}}$ & Rank \\
\hline$A_{1}$ & 1.28 & 0.00 & 1.00 & 1.00 & 1.00 & 1 \\
\hline$A_{2}$ & 0.00 & 0.30 & 0.00 & 0.79 & 0.40 & 3 \\
\hline$A_{3}$ & 0.53 & 0.06 & 0.41 & 0.96 & 0.68 & 2 \\
\hline$A_{4}$ & 0.00 & 1.45 & 0.00 & 0.00 & 0.00 & 4 \\
\hline
\end{tabular}

\section{CONCLUSIONS}

In modern organizations, there have been major changes in the way of business doing. The rapid development of the Internet and information and communication technologies has influenced change in the way of trading. Thus, trade from classical stores is moving towards online trade. Therefore, due to the numerous advantages offered by e-commerce, an increasing number of customers decide to purchase online. Online shopping is becoming an increasingly common way of shopping, and in order for a website to succeed, it has to meet many customers' needs and expectations. Websites are being attributed a vital role by organizations in order for organizations to promote their products and services; for companies to be competitive, they will have to combine online sales and traditional sales channels, thus taking advantage of both. 
A new approach to the evaluation and ranking of websites in the textile industry is the subject matter of consideration in this paper. The proposed approach is based on the use of the EDAS method for the selection of the alternative, i.e. websites, whereas the "quality-in-use" ISO/IEC 9126-4 criteria were used to evaluate the websites. After the presented numerical example of the evaluation of the websites in the textile industry, the alternative denoted as $A_{1}$ is the best-ranked in terms of the evaluation criteria. The usability, effectiveness, simplicity, applicability and adaptivity of the proposed approach is tested and verified in the considered numerical example regarding the evaluation of the websites in the textile industry.

\section{BIBLIOGRAPHY}

[1] Petrović, G., Urošević, S., Karabašević, D., Maksimović, M. (2017). State and perspectives of textile industry development in Serbia. In: Tekstilna industrija, 2017, vol. 65, issue 3, pp. 4-8.

[2] Urošević, S., Đorđević, D., Cvijanović, J. M. Značaj doradnih poslova za razvoj tekstilne i odevne industrija Srbije u procesu tranzicije. In: Industrija, 2009, vol. 37, issue 2, pp. 97-125.

[3] Krstić, J. Integration companies in Serbian textile industry clusters to increase performance. In: Tekstilna industrija, 2016, vol. 64, issue 1, pp. 46-52.

[4] Bratucu, G., Epuran, G., Gârdan, D. A., Bumbas, F., Zamfirache, A., Gârdan, I. P. The evolution of textile and clothing industry in Romania: an analysis from the perspective of imports and exports determinants/Evolutia industriei textile si de confectii din România: analiza din perspectiva determinantilor. In: Industria Textila, 2017 , vol. 68, issue 2, pp. 147-155.

[5] Ghiassi, M., Spera, C. Defining the Internet-based supply chain system for mass customized markets. In: Computers \& Industrial Engineering, 2003, vol. 45, issue 1, pp. 17-41.

[6] Mihajlović, M. Marketing e-kastemerizacije i razvoj Interneta - Srbija. In: Sinteza 2014-Impact of the Internet on Business Activities in Serbia and Worldwide, 2014, pp. 101-104.

[7] Hodge, G., Cagle, C. Business-to-business e-business models: classification and textile industry implications. In: AUTEX Research Journal, 2004, vol. 4, issue 4, pp. 211-227.

[8] Lee, Y., Kozar, K. A. Investigating the effect of website quality on e-business success: An analytic hierarchy process (AHP) approach. In: Decision support systems, 2006, vol. 42, issue 3, pp. 1383-1401.

[9] Al-Manasra, E., Khair, M., Zaid, S. A., Taher Qutaishat, F. Investigating the impact of website quality on consumers satisfaction in Jordanian telecommunication sector. In: Arab Economic and Business Journal, 2013, vol. 8, issue 1-2, pp. 31-37.

[10] Lin, H. F. The impact of website quality dimensions on customer satisfaction in the B2C e-commerce context. In: Total Quality Management and Business Excellence, 2007, vol. 18, issue 4, pp. 363-378.

[11] Kim, S., Stoel, L. Apparel retailers: website quality dimensions and satisfaction. In: Journal of Retailing and Consumer Services, 2004, pp. vol. 11, issue 2, pp. 109-117.

[12] Barnes, S. J., Vidgen, R. An evaluation of cyber-bookshops: the WebQual method. In: International Journal of Electronic Commerce, 2001, vol. 6, issue 1, pp. 11-30.

[13] Parasuraman, A., Zeithaml, V. A., Berry, L. L. A conceptual model of service quality and its implications for future research. In: the Journal of Marketing, 1985, pp. 41-50.

[14] Jung, H. W., Kim, S. G., Chung, C. S. Measuring software product quality: A survey of ISO/IEC 9126. In: IEEE software, 2004, vol. 21, issue 5, pp. 88-92.

[15] Azuma, M. SQuaRE: the next generation of the ISO/IEC 9126 and 14598 international standards series on software product quality. In: ESCOM European Software Control and Metrics conference, 2001, pp. 337-346.

[16] Karabasevic, D., Zavadskas, E. K., Turskis, Z., Stanujkic, D. The framework for the selection of personnel based on the SWARA and ARAS methods under uncertainties. In: Informatica, 2016, vol. 27, issue 1, pp. 49-65.

[17] Yu, X., Guo, S., Guo, J., Huang, X. Rank B2C e-commerce websites in e-alliance based on AHP and fuzzy TOPSIS. In: Expert Systems with Applications, 2011, vol. 38, issue 4, pp. 3550-3557.

[18] Akincilar, A., Dagdeviren, M. A hybrid multi-criteria decision making model to evaluate hotel websites. In: International Journal of Hospitality Management, 2014, vol. 36, pp. 263-271.

[19] Chung, Y. F., Liu, S. H., Wang, C. H., Pang, C. T. Applying fuzzy MCDM methods to the evaluation on portal website service quality. In: The SIJ Transactions on Computer Science Engineering \& its Applications, 2015, vol. 3, pp. 8-15.

[20] Stanujkic, D., Zavadskas, E. K., Tamosaitiene, J. An approach to measuring website quality in the rural tourism industry based on Atanassov intuitionistic fuzzy sets. In: E+M Ekonomie a Management, 2015, vol. 18, issue 4, pp. 84-199.

[21] Liang, R., Wang, J., Zhang, H. Evaluation of e-commerce websites: An integrated approach under a single-valued trapezoidal neutrosophic environment. In: Knowledge-Based Systems, 2017, issue 135, pp. 44-59.

[22] Keshavarz Ghorabaee, M., Zavadskas, E. K., Olfat, L., Turskis, Z. Multi-criteria inventory classification using a new method of evaluation based on distance from average solution (EDAS). In: Informatica, 2015, vol. 26, issue 3, pp. 435-451.

[23] Ghorabaee, M. K., Zavadskas, E. K., Amiri, M., Turskis, Z. Extended EDAS method for fuzzy multi-criteria decisionmaking: an application to supplier selection. In: International Journal of Computers Communications \& Control, 2016, vol. 11, issue 3, pp. 358-371.

[24] Kahraman, C., Keshavarz Ghorabaee, M., Zavadskas, E. K., Cevik Onar, S., Yazdani, M., Oztaysi, B. Intuitionistic fuzzy EDAS method: an application to solid waste disposal site selection. In: Journal of Environmental Engineering and Landscape Management, 2017, vol. 25, issue 1, pp. 1-12.

[25] Stanujkic, D., Zavadskas, E. K., Keshavarz Ghorabaee, M., Turskis, Z. An extension of the EDAS method based on the use of interval grey numbers. In: Studies in Informatics and Control, 2017, vol. 26, issue 1, pp. 5-12.

[26] Keshavarz Ghorabaee, M., Amiri, M., Zavadskas, E. K., Turskis, Z., Antucheviciene, J. A new multi-criteria model based on interval type-2 fuzzy sets and EDAS method for supplier evaluation and order allocation with environmental considerations. In: Computers \& Industrial Engineering, 2017, issue 112, pp. 156-174. 
[27] Keshavarz Ghorabaee, M., Amiri, M., Zavadskas, E. K., Turskis, Z., Antucheviciene, J. Stochastic EDAS method for multi-criteria decision-making with normally distributed data. In: Journal of Intelligent \& Fuzzy Systems, 2017, vol. 33, issue 3, pp. 1627-1638.

[28] Keshavarz Ghorabaee, M., Amiri, M., Zavadskas, E. K., Turskis, Z., Antucheviciene, J. A new hybrid simulationbased assignment approach for evaluating airlines with multiple service quality criteria. In: Journal of Air Transport Management, 2017, issue 63, pp. 45-60.

[29] Keshavarz Ghorabaee, M., Amiri, M., Zavadskas, E. K., Turskis, Z. Multi-criteria group decision-making using an extended EDAS method with interval type-2 fuzzy sets. In: Ekonomika a management, 2017, vol. 20, issue 1, pp. $48-68$.

[30] Keshavarz Ghorabaee, M., Amiri, M., Zavadskas, E. K., Antucheviciene, J. A new hybrid fuzzy MCDM approach for evaluation of construction equipment with sustainability considerations. In: Archives of Civil and Mechanical Engineering, 2018, vol. 18, issue 1, pp. 32-49.

[31] Peng, X., Dai, J., Yuan, H. Interval-valued fuzzy soft decision making methods based on MABAC, similarity measure and EDAS. In: Fundamenta Informaticae, 2017, vol. 152, issue 4, pp. 373-396.

[32] Peng, X., Liu, C. Algorithms for neutrosophic soft decision making based on EDAS, new similarity measure and level soft set. In: Journal of Intelligent \& Fuzzy Systems, 2017, vol. 32, issue 1, pp. 955-968.

[33] Ren, J., Toniolo, S. Life cycle sustainability decision-support framework for ranking of hydrogen production pathways under uncertainties: An interval multi-criteria decision making approach. In: Journal of Cleaner Production, 2018, issue 175, pp. 222-236.

[34] Juodagalvienè, B., Turskis, Z., Šaparauskas, J., Endriukaitytè, A. Integrated multi-criteria evaluation of house's plan shape based on the EDAS and SWARA methods. In: Engineering Structures and Technologies, 2017, vol. 9, issue 3, pp. 117-125.

[35] Keshavarz Ghorabaee, M., Amiri, M., Olfat, L., Khatami Firouzabadi, S. A. Designing a multi-product multi-period supply chain network with reverse logistics and multiple objectives under uncertainty. In: Technological and Economic Development of Economy, 2017, vol. 23, issue 3, pp. 520-548.

[36] Trinkūnienè, E., Podvezko, V., Zavadskas, E. K., Jokšienè, I., Vinogradova, I., Trinkūnas, V. Evaluation of quality assurance in contractor contracts by multi-attribute decision-making methods. In: Economic research-Ekonomska istraživanja, 2017, vol. 30, issue 1, pp. 1152-1180.

[37] Kersuliene, V., Zavadskas, E. K., Turskis, Z. Selection of rational dispute resolution method by applying new step-wise weight assessment ratio analysis (SWARA). In: Journal of Business Economics and Management, 2010, vol. 11, issue 2, pp. 243-258.

[38] Zolfani, S. H., Zavadskas, E. K., Turskis, Z. Design of products with both International and Local perspectives based on Yin-Yang balance theory and SWARA method. In: Economic Research-Ekonomska Istraživanja, 2013, vol. 26, issue 2, pp. 153-166.

[39] Zolfani, S. H., Saparauskas, J. New application of SWARA method in prioritizing sustainability assessment indicators of energy system. In: Engineering Economics, 2013, vol. 24, issue 5, pp. 408-414.

[40] Stanujkic, D., Karabasevic, D., Zavadskas, E. K. A framework for the selection of a packaging design based on the SWARA method. Inzinerine Ekonomika-Engineering Economics, 2015, vol. 26, issue 2, pp. 181-187.

[41] Stanujkic, D., Zavadskas, E. K., Karabasevic, D., Turskis, Z., Keršulienè, V. New group decision-making ARCAS approach based on the integration of the SWARA and the ARAS methods adapted for negotiations. In: Journal of Business Economics and Management, 2017, vol. 18, issue 4, pp. 599-618.

[42] Karabasevic, D., Stanujkic, D., Urosevic, S., Popovic, G., Maksimovic, M. An approach to criteria weights determination by integrating the Delphi and the adapted SWARA methods. In: Management: Journal of Sustainable Business and Management Solutions in Emerging Economies, 2017, vol. 22, issue 3, pp. 15-25.

[43] Stanujkic, D., Karabasevic, D., Zavadskas, E. K. A new approach for selecting alternatives based on the adapted weighted sum and the SWARA methods: A case of personnel selection. In: Economic Computation \& Economic Cybernetics Studies \& Research, 2017, vol. 51, issue 3, pp. 39-56.

\section{Authors:}

Asst. Professor DARJAN KARABASEVIC ${ }^{1}$

Assoc. Professor DRAGISA STANUJKIC ${ }^{2}$

Assoc. Professor MIODRAG BRAZKOVIC ${ }^{1}$

Asst. Professor MLADJAN MAKSIMOVIC ${ }^{1}$ Asst. PAVLE BRZAKOVIC ${ }^{1}$

${ }^{1}$ University Business Academy in Novi Sad, Faculty of Applied Management, Economics and Finance,

Jevrejska 24, 11000, Belgrade, Serbia

e-mail:darjan.karabasevic@mef.edu.rs; miodrag.brzakovic@mef.edu.rs; mladjan.maksimovic@mef.edu.rs; pavle.brzakovic@mef.edu.rs

2University of Belgrade, Technical Faculty in Bor, Vojske Jugoslavije 12, 19210, Bor, Serbia

e-mail: dstanujkic@tfbor.bg.ac.rs

Corresponding author:

DARJAN KARABASEVIC

e-mail: darjan.karabasevic@mef.edu.rs 